\title{
Central pontine myelinolysis
}

\author{
Reuben Grech, Leo Galvin, Paul Brennan, John Thornton
}

Department of Neuroradiology, Beaumont Hospital, Dublin, Ireland

\section{Correspondence to}

Dr Reuben Grech, reubengrech@yahoo.com

\section{DESCRIPTION}

\section{Case report}

A 56-year-old gentleman was referred to the A\&E department following an episode of loss of consciousness. His medical and surgical history was unremarkable except for a background history of alcohol dependency. Serological tests revealed a serum sodium concentration of $118 \mathrm{mEq} / \mathrm{l}$. The patient developed acute pseudobulbar palsy less than $24 \mathrm{~h}$ after admission and an urgent MRI of the brain was requested.

\section{DISCUSSION}

Central pontine myelinolysis is an acute noninflammatory demyelinating disorder first described by Adams et al in 1958. It is a rare condition that predominantly affects the pons but may involve extrapontine structures including the midbrain, thalamus and cerebellum. The condition was originally described in patients with severe hyponatraemia, particularly in the setting of alcoholism and malnutrition. It has since been linked to diabetes mellitus, AIDS and hepatic failure. ${ }^{1}$ Central pontine myelinolysis is precipitated by the rapid correction of chronic severe hyponatraemia (defined as serum sodium $<120 \mathrm{mEq} / \mathrm{l}$ ). The pathophysiology is still not well understood.

Presentation can be catastrophic with pseudobulbar palsy, spastic tetraparesis and the 'locked-in' syndrome. ${ }^{2}$ MRI is the imaging modality of choice (figures 1 and 2). Diffusion-weighted imaging is particularly useful and becomes positive within few hours of symptom onset. ${ }^{3}$ The pontine abnormality characteristically spares the ventrolateral pons and corticospinal tracts.

The overall prognosis is poor. Prevention is crucial and requires cautious correction of chronic hyponatraemia. Most experts would advocate correction of serum sodium concentration at no more than $10 \mathrm{mmol} / \mathrm{/} /$ day. Treatment is supportive and aims to prevent complications such as deep vein thrombosis and aspiration pneumonia.

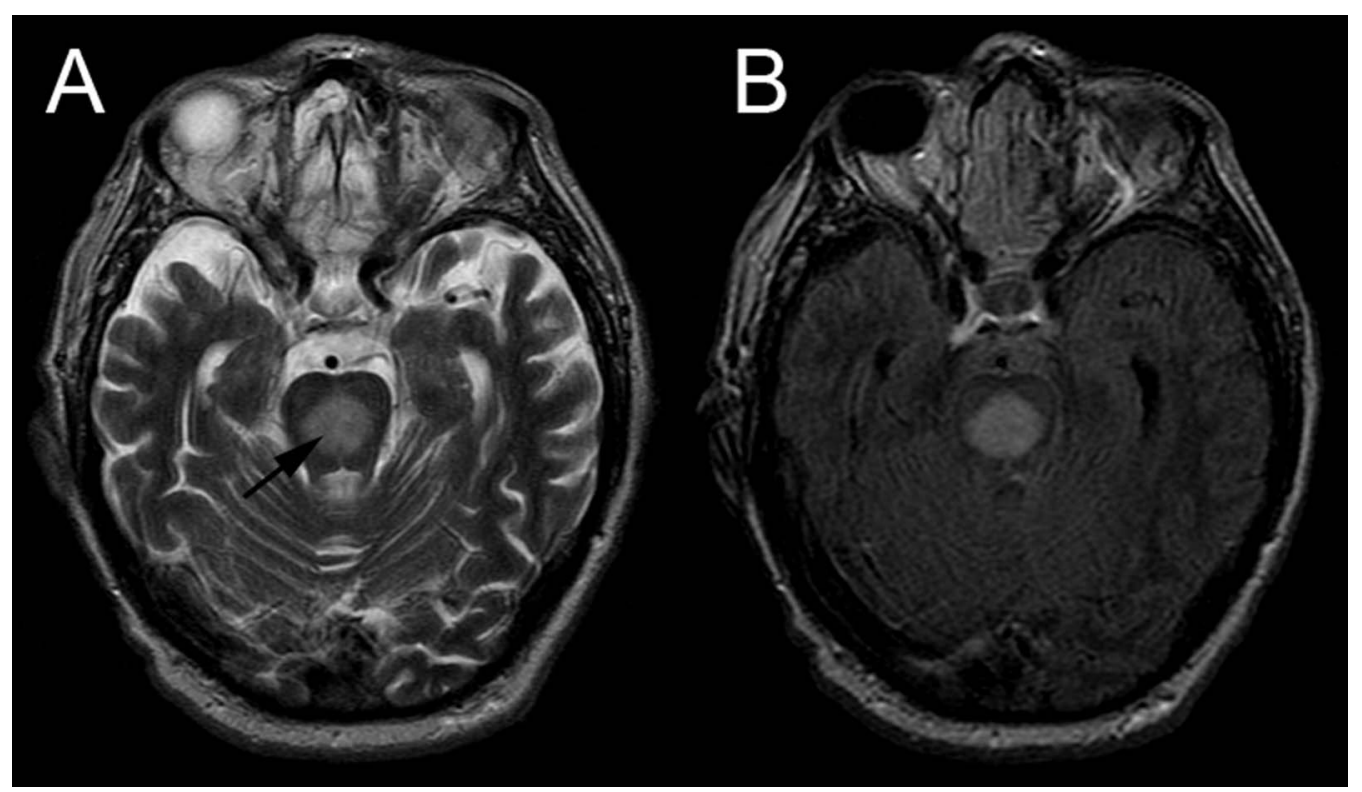

Figure 1 T2 (A) and fluid-attenuated inversion recovery (B) images demonstrate a central hyperintense lesion within the pons. 


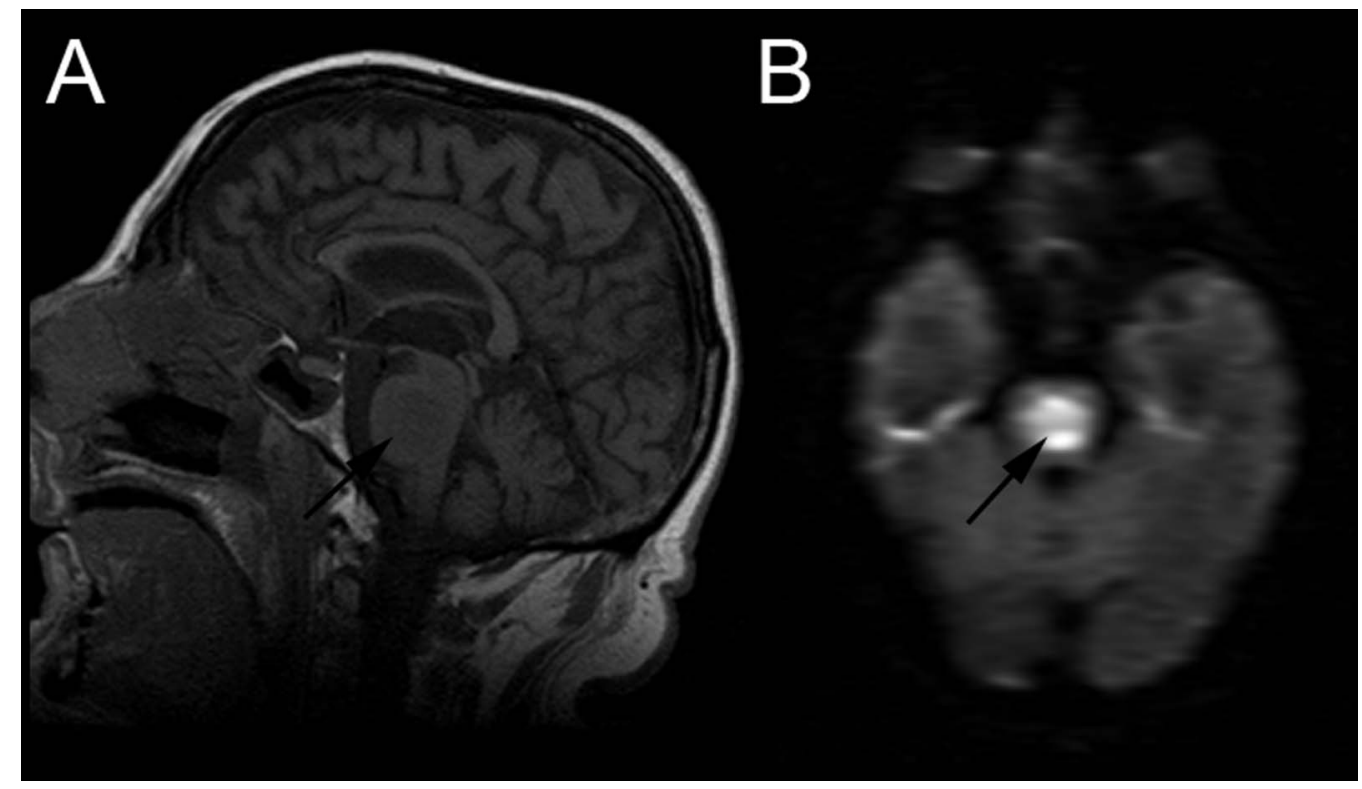

Figure 2 The lesion is hypointense on T1 (A) and hyperintense on diffusion-weighted imaging (B) sequences. Diffusion restriction is seen within $24 \mathrm{~h}$ of symptom onset. Sparing of the ventrolateral longitudinal fibres and corticospinal tracts is characteristic.

\section{Learning points}

- Central pontine myelinolysis is an acute non-inflammatory demyelinating disorder.

- It is precipitated by the rapid correction of severe chronic hyponatraemia.

- MRI is the imaging modality of choice with diffusion-weighted imaging becoming positive within a few hours of symptom onset.
Competing interests None.

Patient consent Obtained.

Provenance and peer review Not commissioned; externally peer reviewed.

\section{REFERENCES}

1 Graff-Radford J, Fugate JE, Kaufmann TJ, et al. Clinical and radiologic correlations of central pontine myelinolysis syndrome. Mayo Clin Proc 2011;86:1063-7.

2 Martin PJ, Young CA. Central pontine myelinolysis: clinical and MRI correlates. Postgrad Med J 1995;71:430-2.

3 Ruzeka KA, Campeaua NG, Millera GM. Early diagnosis of central pontine myelinolysis with diffusion-weighted imaging. AJNR Am I Neuroradiol 2004;25:210-13.

Copyright 2013 BMJ Publishing Group. All rights reserved. For permission to reuse any of this content visit http://group.bmj.com/group/rights-licensing/permissions.

BMJ Case Report Fellows may re-use this article for personal use and teaching without any further permission.

Become a Fellow of BMJ Case Reports today and you can:

- Submit as many cases as you like

- Enjoy fast sympathetic peer review and rapid publication of accepted articles

- Access all the published articles

- Re-use any of the published material for personal use and teaching without further permission

For information on Institutional Fellowships contact consortiasales@bmjgroup.com

Visit casereports.bmj.com for more articles like this and to become a Fellow 